\title{
Evaluasi Program Pendidikan Kesetaraan Paket A Bagi Anak Putus Sekolah di Kabupaten Gorontalo
}

\author{
${ }^{1}$ Lia Nurhayati, ${ }^{2}$ Srihandayani Suprapto \\ ${ }^{\text {I}}$ Program Studi Guru Sekolah Dasar, Fakultas Keguruan dan Ilmu Pendidikan \\ ${ }^{2}$ Program Studi Admnistrasi Publik, Fakultas Ekonomi dan Ilmu Sosial \\ Universitas Mhammadiyah Gorontalo,Indonesia 96181 \\ E-mail: ${ }^{1}$ lianurahayati@umgo.ac.id ; ${ }^{2}$ srihandayani_suprapto@umgo.ac.id
}

Received: 25 Oktober 2020; Revised: 29 November 2020; Accepted: 28 Desember 2020

\begin{abstract}
This study aims to evaluate the Paket A equivalency education program for school dropouts in Gorontalo District. This program evaluation research uses descriptive method with the CIPP model (Context, Input, Process, and Product). The data analysis in this study was carried out in a qualitative descriptive manner, then the qualitative data were analyzed using thematic analysis, namely comparing the data at each stage of the CIPP then concluding. In this thematic analysis, an analysis flow is adopted which consists of data collection, data presentation, data reduction and conclusion verification. The results showed that the implementation of the Paket A equivalency education program in Gorontalo District has been optimal. This is based on the objective standard criteria that have been set in this evaluation study. The length of learning for the Paket A Equivalent Education program for each class or class is adjusted to the curriculum structure above. The learning process includes academic learning, namely the efforts made by the tutor to provide insight and knowledge to learning citizens facilitated by the tutor.
\end{abstract}

Keywords: Program; Evaluation; Education

\begin{abstract}
Abstrak
Penelitian ini bertujuan mengevaluasi program pendidikan kesetaraan paket A bagi anak putus sekolah di Kabupaten Gorontalo. Penelitian evaluasi program ini menggunakan metode deskriptif dengan model CIPP (Context, Input, Process, dan Product). Analisis data dalam penelitian ini dilaksanakan secara deskriptif kualitatif, kemudian data kualitatif dianalisis menggunakan analisis tematik yaitu membandingkan data pada setiap tahapan CIPP kemudian disimpulkan. Dalam analisis tematik ini, ditempuh alur analisis yang terdiri atas pengumpulan data, penyajian data, reduksi data dan kesimpulan verifikasi. Hasil penelitian menunjukkan bahwa sudah optimalnya pelaksanaan program pendidikan kesetaraan paket A di Kabupaten Gorontalo, Hal ini berdasarkan pada kriteria standar objektif yang telah ditetapkan dalam penelitian evaluasi ini. Lama pembelajaran program Pendidikan Kesetaraan Paket A untuk setiap angkatan atau kelas disesuaikan dengan struktur kurikulum diatas. Proses pembelajaran meliputi pembelajaran akademik, yaitu upaya yang dilakukan tutor untuk memberikan wawasan dan ilmu pengetahuan kepada warga belajar yang difasilitasi oleh tutor.
\end{abstract}

Kata Kunci: Program; Evaluasi; Pendidikan

Link DOI : http://dx.doi.org/10.31314/pjia.9.2.168-175.2020 


\section{PENDAHULUAN}

Permasalahan putus sekolah pada jenjang Sekolah Dasar merupakan hal yang perlu mendapat perhatian dan perlu dicarikan pemecahannya. Karena kasus putus sekolah tidak saja merugikan siswa yang bersangkutan, tetapi juga membawa implikasi yang kurang baik pada perekonomian Negara, seperti meningkatnya jumlah pengangguran, bertambahnya tenaga kerja yang minim ketrampilan dan keahlian, bahkan lebih dari itu kasus putus sekolah dipandang berpengaruh pada pembangunan khususnya pembangunan sumberdaya manusia yang berkualitas (Riniwati, 2016; Oktriawan, 2017).

Mengacu pada UUD 1945 Pasal 31 ayat 1 dan 2 pada naskah asli, maupun pasal 31 ayat 1 sampai 4 hasil Amandemen UUD 1945 tahun 2003, maka idealnya tidak ada siswa yang mengalami putus sekolah, terutama pada jenjang pendidikan Sekolah Dasar. Tetapi nampaknya di Kabupaten Gorontalo belum sepenuhnya terlaksana dengan baik, hal ini terlihat masih ada beberapa kasus anak putus sekolah di jenjang pendidikan Sekolah Dasar. Hal ini tentunya mendapat perhatian khusus dari Pemerintah daerah setempat guna memenuhi kebutuhan pendidikan dasar yang berimplikasi pada pengembangan sumberdaya manusia yang berkualitas.

Pendidikan kesetaraan merupakan salah satu solusi dari masalah pemenuhan pendidikan dasar, terutama pendidikan di Kabupaten Gorontalo. Pemerintah daerah sudah melaksanakan program pendidikan kesetaraan melalui jalur pendidikan non formal dan hasil pendidikan nonformal dapat dihargai setara dengan hasil program pendidikan formal setelah melalui proses penilaian penyetaraan oleh lembaga yang ditunjuk oleh Pemerintah atau pemerintah daerah dengan mengacu pada standar nasional penilaian. Setiap peserta didik yang lulus ujian program paket $\mathrm{A}$, paket $\mathrm{B}$, paket $\mathrm{C}$ mempunyai hak eligibilitas yang sama dan setara dengan pemegang ijazah SD/MI, SMP/MI, dan SMA/MA untuk mendaftar pada satuan pendidikan yang lebih tinggi.

Program ini ditujukan bagi peserta didik yang berasal dari masyarakat yang kurang beruntung, tidak sekolah, putus sekolah dan putus lanjutan, serta usia produktif yang ingin meningkatkan pengetahuan dan kecakapan hidup, dan warga masyarakat lain yang memerlukan layanan khusus dalam memenuhi kebutuhan belajarnya sebagai dampak dari perubahan peningkatan taraf hidup, ilmu pengetahuan dan teknologi. Oleh karena itu diperlukan evaluasi dari kebjiakan atau program ini.

Evaluasi adalah kegiatan untuk mengumpulkan informasi tentang bekerjanya sesuatu, yang selanjutnya informasi tersebut digunakan untuk menentukan alternatif yang tepat dalam mengambil keputusan (Kaplan \& Maxwell, 2005; Watkins et al., 2012).

Evaluasi sendiri bertujuan untuk mengumpulkan, menganalisis, dan menyajikan informasi yang bermanfaat mengenai objek evaluasi, menilainya dengan membandingkannya dengan indikator dan hasilnya dipergunakan untuk mengambil keputusan mengenai objek evaluasi (Akbar \& Mohi,2018).

Fungsi utama evaluasi dalam hal ini adalah menyediakan informasi-informasi yang berguna bagi pihak decision maker untuk menentukan kebijakan yang akan diambil berdasarkan evaluasi yang telah dilakukan. dua dasar kegiatan dalam evaluasi, yaitu description dan judgement dan membedakan adanya tiga tahap dalam program pendidikan yaitu context, process dan outcomes (Schatt et al., 2016; Amir, 2020). Apabila menilai suatu program Copyright @ 2020, Publik (Jurnal Ilmu Administrasi), ISSN: 2301-573X (Print), ISSN: 2581-2084 (Online) 
pendidikan, maka harus melakukan perbandingan yang relatif antara satu program dengan yang lainnya (Lyons et al., 2006; Norbutaevich, 2020). Dalam model ini antencedent, transaction dan Outcomes data dibandingkan tidak hanya untuk menentukan apakah ada perbedaan antara tujuan dengan keadaan yang sebenarnya, tetapi juga dibandingkan dengan standar yang absolut untuk menilai manfaat program (Congdon \& MeQueen, 2000; DuBois et al., 2011). Penulis merasa perlu melakukan penelitian tentang pelaksanaan program dan mengukur keberhasilan dari program tersebut dengan menggunakan penelitan evaluasi dimana penelitan ini bermaksud mengevaluasi program pendidikan kesetaraan paket A yang dilaksanakan di Kabupaten Gorontalo. Metode evaluasi yang digunakan adalah CIPP (Context, Input, Process, Product). Dimana yang termasuk komponen context adalah kebijakan dari program kejar paket A komponen input adalah sumberdaya, komponen proses adalah pelaksanaan dari program, komponen produk adalah output atau hasil belajar. Penelitian ini bertujuan mengevaluasi program pendidikan kesetaraan paket A bagi anak putus sekolah di Kabupaten Gorontalo.

\section{METODE PENELITIAN}

Penelitian evaluasi program ini menggunakan metode deskriptif dengan model CIPP (Context, Input, Process, dan Product) adalah model analisis data yang diperkenalkan oleh Stufflebeam (1971). Data yang dibutuhkan dalam penelitian ini adalah data yang terkait dengan pelaksanaan program pendidikan kesetaraan paket A dengan menggunakan model evaluasi CIPP terhadap komponenkomponen context, input, process dan product sesuai dengan indikator yang ada.
Oleh karena itu tekhnik pengumpulan data yang digunakan adalah observasi, wawancara dan dokumentasi. Analisis data dalam penelitian ini dilaksanakan secara deskriptif kualitatif, kemudian data kualitatif dianalisis menggunakan analisis tematik yaitu membandingkan data pada setiap tahapan CIPP kemudian disimpulkan. Dalam analisis tematik ini, ditempuh alur analisis yang terdiri atas pengumpulan data, penyajian data, reduksi data dan kesimpulan verifikasi.

\section{HASIL DAN PEMBAHASAN \\ Hasil Evaluasi Konteks}

Pelaksanaan program pendidikan kesetaraan paket A telah sesuai dengan kebijakan/ berdasarkan acuan, Dimana kebijakan yang dimaksud antara lain: Instruksi Presiden Nomor 5 Tahun 2006 tentang Gerakan Nasional Percepatan Penuntasan Wajib Belajar Pendidikan Dasar Sembilan Tahun dan Pemberantasan Buta Aksara, Peraturan Menteri Pendidikan Nasional Nomor 3 Tahun 2008 tentang Standar Proses Pendidikan Kesetaraan Program Paket A,B,C; Peraturan Menteri Pendidikan Nasional Nomor 44 Tahun 2009 Tentang Standar Pengelolaan Pendidikan Program Paket A, Paket B, Paket C; Petunjuk Teknis Penyelenggaraan Program Pendidikan Kesetaraan Paket A.

\section{Hasil Evaluasi Input}

Berdasarkan hasil wawancara, dapat ditarik kesimpulan tutor sudah memenuhi kriteria/ standar yang telah ditetapkan dalam juknis yaitu (1) memiliki kualifikasi/ kompetensi akademik sesuai bidang studi atau mata pelajaran yang dibelajarkan. Kualifikasi tutor minimal S1 dari berbagai disiplin ilmu, tetapi diutamakan yang memiliki basic ilmu keguruan. (2) Sehat jasmani dan rohani, hal ini dibuktikan sebelum merekrut calon tutor, pengelola 


\begin{tabular}{llll}
\hline PKBM melalui Diknas & Kabupaten & memiliki perpustakaan sendiri; (3) \\
mensyaratkan untuk & melakukan & tersedianya media pembelajaran, seperti \\
pemeriksaan dokter dengan & dibuktikan & alat peraga.
\end{tabular}
surat sehat dari dokter; (3) memiliki pengalaman dan kompetensi pembelajaran orang dewasa, tutor memiliki kemampuan dan pengalaman dalam mengajar, sebagian besar tutor dalam pembelajaran adalah guru-guru yang mengajar di sekolahsekolah dasar negeri/ swasta atau mahasiswa keguruan semester akhir sehingga diharapkan ilmu yang didapat peserta didik mempunyai nilai yang sama dengan pendidikan formal pada umumnya; (4) bersedia membelajarkan warga belajar sampai akhir program, sebelum mengajar, tutor membuat pakta integritas/ surat pernyataan kesanggupan mengajar sampai berakhirnya program selama 3 tahun atau disesuaikan dengan kebutuhan; diprioritaskan bagi yang telah mengikuti pelatihan tutor pendidikan kesetaraan. Tutor bagi pendidikan kesetaraan memiliki metode tersendiri dalam hal pembelajaran sehingga Diknas mempunyai program pelatihan khusus bagi calon-calon tutor yang kemudian nantinya calon-calon tutor tersebut memiliki kualifikasi atau kompetensi dalam mengajar di program pendidikan kesetaraan.

\section{Sarana Prasarana}

Berdasarkan hasil observasi dan wawancara, dapat dilihat bahwa sarana prasarana pelaksanaan program pendidikan kesetaraan paket A di setiap PKBM sudah memenuhi standar kriteria, yaitu antara lain (1) tersedianya ruangan untuk proses pembelajaran dan pelatihan beserta kelengkapannya, ruangan mampu menampung 30 sampai 40 peserta didik; (2) tersedianya alat dan bahan pembelajaran, seperti whiteboard/ papan tulis, spidol/ kapur, meja dan kursi tutor, meja dan kursi warga belajar, lemari buku, buku-buku pelajaran, bahkan ada salah

\section{Kurikulum}

Untuk membekali pengetahuan, ketrampilan, dan sikap warga belajar sebagai peserta program pendidikan kesetaraan paket A penyelenggara program menyusun silabus pembelajaran/ pelatihan yang mengacu pada standar kompetensi lulusan dan kompetensi dasar setiap mata pelajaran yang ditentukan dalam setiap tahapan pembelajaran. Berdasarkan peraturan Menteri Pendidikan Nasional Nomor 14 tahun 2007 tentang Standar Isi untuk Program Paket A, Program Paket B, Program Paket $\mathrm{C}$, maka struktur kurikulum program pendidikan kesetaraan Paket A merupakan pola susunan mata pelajaran dan beban belajar yang harus ditempuh oleh peserta didik dalam kegiatan pembelajaran, meliputi mata pelajaran dan beban satuan kredit kompetensi (SKK).

Beban belajar program pendidikan kesetaraan Paket A dinyatakan dalam satuan kredit kompetensi (SKK) yang menunjukkan bobot kompetensi yang harus dicapai oleh peserta didik dalam mengikuti program pembelajaran, baik melalui tatap muka, pra ketrampilan dan atau kegiatan mandiri.

SKK merupakan penghargaan terhadap pencapaian kompetensi sebagai hasil belajar peserta didik dalam menguasai suatu mata pelajaran. SKK diperhitungkan untuk setiap mata pelajaran yang terdapat dalam struktur kurikulum. Satu SKK dihitung berdasarkan pertimbangan muatan SK dan KD tiap mata pelajaran. SKK dapat digunakan untuk alih kredit kompetensi yang diperoleh dari jalur pendidikan informal, formal, kursus, keahlian dan kegiatan mandiri. 
Tabel 1 Struktur sebaran mata pelajaran Program Pendidikan Kesetaraan Paket A

\begin{tabular}{|c|c|c|c|c|}
\hline \multirow[b]{2}{*}{ No } & \multirow[b]{2}{*}{ Mata Pelajaran } & \multicolumn{3}{|c|}{ Bobot Satuan Kredit Kompetensi (SKK) } \\
\hline & & $\begin{array}{c}\text { Tingkatan 1/ Drajat } \\
\text { awal Setara Kelas } \\
\text { I-III }\end{array}$ & $\begin{array}{c}\text { Tingkatan 2/ Drajat } \\
\text { Dasar Setara Kelas } \\
\text { IV-V }\end{array}$ & Jumlah \\
\hline 1. & $\begin{array}{l}\text { Pendidikan } \\
\text { Agama }\end{array}$ & 9 & 9 & 18 \\
\hline 2. & $\begin{array}{l}\text { Pendidikan } \\
\text { Kewarganegara } \\
\text { an }\end{array}$ & 9 & 9 & 18 \\
\hline 3. & $\begin{array}{l}\text { Bahasa } \\
\text { Indonesia }\end{array}$ & 15 & 15 & 30 \\
\hline 4. & Matematika & 15 & 15 & 30 \\
\hline 5. & $\begin{array}{l}\text { Ilmu } \\
\text { Pengetahuan } \\
\text { Alam }\end{array}$ & 12 & 12 & 24 \\
\hline 6. & $\begin{array}{l}\text { Ilmu } \\
\text { Pengetahuan } \\
\text { Sosial }\end{array}$ & 9 & 9 & 18 \\
\hline 7. & Seni Budaya & 6 & 6 & 12 \\
\hline 8. & $\begin{array}{l}\text { Pendidikan } \\
\text { Jasmani, } \\
\text { Olahraga dan } \\
\text { Kesehatan }\end{array}$ & 6 & 6 & 12 \\
\hline 9. & $\begin{array}{l}\text { Ketrampilan } \\
\text { Fungsional }{ }^{*}\end{array}$ & 9 & 9 & 18 \\
\hline 10. & $\underset{\substack{* * * \\
* *}}{\text { Muatan Lokal }}$ & $\left.6^{* *}\right)$ & $\left.6^{* *}\right)$ & $12^{* *)}$ \\
\hline 11. & $\begin{array}{l}\text { Pengembangan } \\
\text { Kepribadian } \\
\text { Profesional }\end{array}$ & 6 & 6 & 12 \\
\hline & Jumlah & 102 & 102 & 204 \\
\hline
\end{tabular}

\footnotetext{
${ }^{*}$ Pilihan mata pelajaran

**) Substansinya dapat menjadi bagian dari mata pelajaran yang ada, baik mata pelajaran wajib maupun pilihan. SKK untuk substansi muatan lokal termasuk kedalam SKK mata pelajaran yang dimuati. (Sumber : Olahan Data, 2020)
}

Satu SKK adalah satu satuan kompetensi yang dicapai melalui pembelajaran 1 jam tatap muka atau 2 jam tutorial atau 3 jam mandiri, atau kombinasi secara proporsional dari ketiganya. Satu tatap muka yang dimaksud adalah satu jam pembelajaran, yaitu sama dengan 35 menit. Adapun struktur sebaran mata pelajaran Program Pendidikan Kesetaraan Paket A, dapat digambarkan dalam tabel 1 


\section{Dana/ Anggaran}

Dalam pengelolaan anggaran pelaksanaan program pendidikan kesetaraan sudah sesuai dengan Permendikbud Nomor 13 Tahun 2020 tentang petunjuk teknis Dana Alokasi Khusus Nonfisik Bantuan Operasional Penyelenggaraan Pendidikan Anak Usia Dini dan Pendidikan Kesetaraan Tahun Anggaran 2020. Alokasi dan penyaluran DAK Nonfisik BOP PAUD dan BOP Kesetaraan: (a) Besaran dana yang disalurkan ke satuan pendidikan penyelenggara PAUD sebesar Rp 600.000 (Enam Ratus Ribu Rupiah) per peserta didik per tahun; (b) Besaran dana yang disalurkan ke Satuan Pendidikan penyelenggara Pendidikan Kesetaraan Program Paket A sebesar Rp 1.300.000 (Satu Juta Tiga Ratus Ribu Rupiah) per peserta didik per tahun. Adapun dana tersebut akan diberikan kepada pengelola PKBM ketika mereka sudah melaporkan jumlah peserta didik.

\section{Hasil Evaluasi Proses}

Lama pembelajaran program Pendidikan Kesetaraan Paket A untuk setiap angkatan atau kelas disesuaikan dengan struktur kurikulum diatas. Proses pembelajaran meliputi pembelajaran akademik, yaitu upaya yang dilakukan tutor untuk memberikan wawasan dan ilmu pengetahuan kepada warga belajar yang difasilitasi oleh tutor. Pembelajaran akademik dilakukan sesuai dengan ketentuan yang diatur dalam standar isi dan standar proses yaitu pembelajaran dilakukan minimal 2 hari dalam seminggu @ 3 jam pelajaran, atau 3 hari dalam seminggu@2 jam pelajaran; pembelajaran dilakukan dengan tatap muka, tutorial, dan/ atau mandiri; materi pembelajaran mengacu kepada standar kompetensi lulusan pendidikan dasar dan menengah (Permendikbud Nomor 54 Tahun 2013 Tentang Standar Kompetensi Lulusan Copyright @ 2020 , Publik (Jurnal Ilmu Administrasi), ISSN: 2301-573X (Print), ISSN: 2581-2084 (Online)
Pendidikan Dasar dan Menengah). Agar proses pembelajaran akademik mengarah kepada tujuan dan hasil yang ingin dicapai, maka tutor wajib melakukan persiapan dengan membuat Rencana Pelaksanaan Pembelajaran (RPP) berdasarkan silabus yang dibuat oleh Lembaga penyelenggara program.

Evaluasi pembelajaran dilakukan setiap akhir semester, sesuai dengan materi pembelajaran yang telah diberikan oleh tutor. Waktu pelaksanaan setiap akhir tahun ajaran, evaluasi hasil belajar bisa langsung dilaksanakan di lokasi/ tempat pembelajaran atau di kantor Diknas dengan ruangan khusus yang disediakan bagi pembelajaran kelas kesetaraan paket $\mathrm{A}$. begitu pula dengan pelaksanaan ujian nasional. Adapun pemberian nilai hasil belajar langsung diberikan oleh Tutor, dan yang mengeluarkan sertifikat/ ijazah kelulusan pendidikan kesetaraan adalah Diknas Pemerintah Kabupaten Gorontalo, dan ijazah tersebut diakui dan bernilai setara dengan pendidikan formal.

\section{Hasil Evaluasi Produk}

Setelah mengikuti program pendidikan kesetaraan paket A bagi anak putus sekolah, menjadikan mereka bisa mengenyam pendidikan dasar sehingga mereka memiliki pengetahuan, ketrampilan dan sikap yang diakui setara dengan lulusan SD/MI, serta mereka memperoleh dasar-dasar kecakapan hidup yang bermanfaat untuk mencari nafkah atau berusaha sendiri dan memungkinkan lulusan program ini dapat meningkatkan pendidikan ke jenjang yang lebih tinggi (melanjutkan pendidikan pada program pendidikan kesetaraan paket $\mathrm{B}$ atau SMP/MTS). Fungsi utama evaluasi dalam hal ini adalah menyediakan informasiinformasi yang berguna bagi pihak decision maker untuk menentukan kebijakan yang akan diambil berdasarkan evaluasi yang telah dilakukan. dua dasar 
kegiatan dalam evaluasi, yaitu description dan judgement dan membedakan adanya tiga tahap dalam program pendidikan yaitu context, process dan outcomes.

\section{PENUTUP}

\section{Kesimpulan}

Secara keseluruhan sesuai dengan temuan-temuan dan hasil evaluasi, menunjukkan sudah optimalnya pelaksanaan program pendidikan kesetaraan paket A di Kabupaten Gorontalo, Hal ini berdasarkan pada kriteria standar objektif yang telah ditetapkan dalam penelitian evaluasi ini. Berdasarkan hasil pengamatan, wawancara dan observasi, pelaksanaan program pendidikan kesetaraan Paket A sudah sesuai dengan petunjuk teknis pelaksanaan yang dikeluarkan oleh Kementrian Pendidikan dan Kebudayaan.

\section{Saran}

Diperlukan pendekatan dalam penjaminan mutu dari lulusan khususnya program Paket A di Kabupaten Gorontalo oleh Dinas Pendidikan Kabupaten dan stakeholder terkait agar program ini senantiasa terjamin kualitas lulusannya, dan hal-hal lain terkait dengan pengembangan program Pendidikan kesetaraan Paket A ini.

\section{DAFTAR PUSTAKA}

Akbar, M. F., \& Mohi, W. K. (2018). Studi Evaluasi Kebijakan (Evaluasi Beberapa Kebijakan di Indonesia). Gorontalo: Ideas Publishing.

Amir, A. (2020). Public Policy Implementation: Study on Educational Budgeting of Palopo. Journal La Sociale, 1(1), 5-11.

Congdon, P. J., \& MeQueen, J. (2000). The stability of rater severity in large-scale

assessment programs. Journal of Educational Measurement, 37(2), 163-178.

DuBois, D. L., Portillo, N., Rhodes, J. E., Silverthorn, N., \& Valentine, J. C. (2011). How effective are mentoring programs for youth? A systematic assessment of the evidence. Psychological Science in the Public Interest, 12(2), 57-91.

Kaplan, B., \& Maxwell, J. A. (2005). Qualitative research methods for evaluating computer information systems. In Evaluating the organizational impact of healthcare information systems (pp. 30-55). Springer, New York, NY.

Lyons, A. C., Palmer, L., Jayaratne, K. S., \& Scherpf, E. (2006). Are we making the grade? A national overview of financial education and program evaluation. Journal of Consumer Affairs, 40(2), 208-235.

Norbutaevich, J. T. (2020). Use of Digital Learning Technologies in Education on the Example of Smart Education. Journal La Edusci, 1(3), 33-37.

Oktriawan, W. (2017). Pengaruh tingkat upah dan tingkat pendidikan terhadap produktivitas tenaga kerja: studi kasus tenaga kerja indutri garment di kabupaten Purwakarta (Doctoral dissertation, UIN Sunan Gunung Djati Bandung).

Riniwati, H. (2016). Manajemen Sumberdaya Manusia: Aktivitas Utama dan Pengembangan SDM. Universitas Brawijaya Press. 
Schatt, A., Doukakis, L., Bessieux-Ollier, C., \& Walliser, E. (2016). Do goodwill impairments by European firms provide useful information to investors?. Accounting in Europe, 13(3), 307-327.

Stufflebeam, D. L. (1971). The relevance of the CIPP evaluation model for educational accountability. ERIC.

Watkins, R., West Meiers, M., \& Visser, Y. (2012). A guide to assessing needs: Essential tools for collecting information, making decisions, and achieving development results. The World Bank. 